\title{
Penerokaan Isu Penguasaan Kemahiran Insaniah Graduan UKM dari Perspektif STOPS
}

\author{
ONG AI LING \\ CHANG PENG KEE \\ ARINA ANIS AZLAN \\ Universiti Kebangsaan Malaysia
}

\begin{abstract}
ABSTRAK
Kemahiran insaniah (soft skills) merupakan kemahiran yang perlu dikuasai oleh pelajar supaya mampu berdaya saing dalam mendapatkan pekerjaan selepas tamat pengajian. Institusi pengajian tinggi atau universiti memainkan peranan yang penting dalam membantu dan membentuk sahsiah pelajar agar mereka mampu menguasai set kemahiran yang diperlukan dalam alam pekerjaan. Tidak dinafikan juga penguasaan kemahiran insaniah graduan berkait dengan isu kebolehpasaran graduan yang sering dibangkitkan. Dengan mengambil pandangan dari perspektif komunikasi, kajian ini dijalankan untuk memahami cara graduan bertindak balas terhadap isu penguasaan kemahiran insaniah berpandukan teori STOPS. Sebanyak 415 responden yang terdiri daripada graduan prasiswazah UKM tahun 2018 telah memberikan maklum balas terhadap survei yang diedarkan. Data dianalisis dengan menggunakan Model Persamaan Struktural (SEM) dibantu perisian IBM-SPSS versi 21 dan IBM-SPSSAMOS. Lima hipotesis yang dicadangkan telah disokong oleh dapatan kajian. Hasil kajian mendapati model pengukuran STOPS mencapai indeks kesepadanan yang baik berdasarkan nilai indeks yang dicadangkan. Nilai koefisien penentuan $\mathrm{R}^{2}$ bagi pemboleh ubah perseptual (antecedent) iaitu pengenalpastian masalah, pengenalpastian kekangan, dan pengenalpastian penglibatan terhadap motivasi situasi dalam penyelesaian masalah adalah .52 yang mana ia menunjukkan hubungan sederhana kuat antara pemboleh ubah. Manakala nilai $\mathrm{R}^{2}$ bagi pemboleh ubah kriteria rujukan dan motivasi terhadap tingkah laku komunikasi (CAPS) adalah .61 yang juga menunjukkan hubungan sederhana kuat. Berdasarkan hasil analisis, institusi pengajian tinggi harus memberi pendedahan yang lebih komprehensif terhadap isu penguasaan kemahiran insaniah supaya meningkatkan kebolehan pelajar dalam pengenalpastian masalah, kekangan dan penglibatan yang mampu menyumbang kepada peningkatan motivasi dalam penyelesaian masalah.
\end{abstract}

Kata kunci: Kemahiran insaniah, graduan, STOPS, SEM, situasi.

\section{Exploring UKM Graduates' Soft Skills Mastery Issue from the Perspective of STOPS}

\begin{abstract}
Soft skills are skills that must be mastered by students in order to compete for job offers after graduating. Institutions of higher learning or universities play a significant role in helping and shaping the students' personalities so that they can master the required set of skills needed in the workplace. It is evident that graduates' soft skills profieciency is directly related to the employability issues which are often raised. Drawing from the communication perspectives, this study sought to explore how local graduates respond towards the ability in mastering soft skills issue based on STOPS theory. A total of 415 respondents sampled from 2018 UKM graduates provided feedback on the survey. Data were analysed using the Structural Equation of Modeling (SEM) with the help of IBM-SPSS version 21 and IBM-SPSS-AMOS software. Five proposed hypotheses have been suported by the findings of the
\end{abstract}


study. Results found that STOPS measurement model achieved the goodness-of-fit indexes. The $R^{2}$ value for the perceptual variables namely problem recognition, constraint recognition, and involvement recognition towards situational motivation in problem solving is .52 which indicated a moderately strong relationship. Furthermore, the $R^{2}$ value for referent criterion and situational motivation towards communicative action in problem solving (CAPS) yielded .61 which also exhibited a moderately strong relationship between variables. Based on that, related parties should provide more comprehensive exposure regarding the soft skills' mastery issue to improve student's ability to recognise the problem, constraints and involvments to contribute to the increment of motivation in problem solving.

Keywords: Soft skills, graduates, STOPS, SEM, situational.

\section{PENGENALAN}

Dalam menuju era Revolusi Industri 4.0 kini, persaingan graduan untuk mendapatkan pekerjaan selepas tamat pengajian menjadi semakin sengit ekoran dari kehendak penguasaaan kemahiran-kemahiran yang diperlukan oleh industri. Hamidah, Rohailin, Siti Zuraydah dan Rusyda (2017) berpendapat bahawa persaingan sedemikian menuntut para graduan untuk bertindak lebih peka terhadap keperluan semasa dalam memenuhi kehendak pasaran pekerjaan. Hal ini adalah kerana kemampuan graduan mendapatkan pekerjaan sejurus menamatkan pengajian merupakan salah satu ukuran kebolehpasaran. Isu kebolehpasaran graduan bukan merupakan sesuatu yang baru malah hangat dibincangkan oleh para penyelidik akademik (Norasmah, 2017). Memetik statistik Laporan Kajian Pengesanan Graduan (Tracer Study) daripada Kementerian Pendidikan Malaysia, seramai 290,282 orang graduan telah menamatkan pengajian pada tahun 2018 namun sejumlah 57,411 atau $19.8 \%$ masih belum mendapat pekerjaan (KPM, 2018).

Keupayaan penguasaan kemahiran insaniah merupakan salah satu faktor yang penting dan relevan kepada mereka yang hendak bekerja dalam industri kelak Tidak dinafikan, pihak universiti telah diberikan tanggungjawab fundamental untuk membimbing serta membentuk sahsiah mahasiswa supaya mampu berdaya saing dalam alam pekerjaan. Fairuzza, Mohamad Nazuir dan Wahid (2011) mengatakan bahawa tahap kemahiran insaniah yang rendah bagi sebilangan besar graduan universiti tempatan di Malaysia telah mengakibatkan berlakunya pengangguran di pasaran kerja yang kompetitif.

Perubahan tren pendidikan yang kian beralih dalam penyesuaian alaf baru, fleksibiliti dalam kursus pendidikan, dan jumlah graduan berkelayakan yang ramai telah mengakibatkan persaingan untuk mendapatkan pekerjaan semakin sukar. Oleh yang demikian, mahasiswa tidak mempunyai pilihan selain dari menambah nilai kepada pencapaian akademik serta mengukuhkan kemahiran insaniah untuk menyerlahkan potensi mereka (Wats \& Wats, 2009). Tambahan pula, sebuah kajian yang dijalankan oleh penyelidik di Universiti Tun Hussein Onn Malaysia menyatakan terdapat jurang di antara kepentingan kemahiran insaniah yang diperlukan di tempat kerja dengan kompetensi graduan dari perspektif Jabatan Sumber Manusia (Fairuzza et al., 2011). Hal ini menunjukkan penguasaan kemahiran insaniah yang strategik dan relevan adalah penting untuk memastikan kelestarian pekerjaan dalam dunia pekerjaan.

Di Malaysia, terdapat banyak kajian-kajian lepas yang memberi penekanan kepada isu penguasaan kemahiran insaniah graduan. Kajian daripada pelbagai sudut dan bidang telah menarik perhatian para penyelidik untuk meneruskan penerokaan terhadap isu ini. Dengan mengambil langkah dari perspektif komunikasi, kajian ini dijalankan untuk memahami faktor dan latar belakang situasi yang menjurus kepada aktiviti pencarian, pemilihan dan 
penyebaran maklumat dalam proses penyelesaian masalah penguasaan kemahiran insaniah graduan.

\section{SOROTAN LITERATUR}

Kemampuan penguasaan kemahiran insaniah graduan merupakan faktor yang sangat diperlukan dalam melahirkan sumber modal insan yang berkualiti selaras dengan kehendak industri semasa kerana kemahiran insaniah bertindak sebagai pelengkap kepada pengetahuan teori dan teknikal. Noor Lela, Noraishah dan Norasmah (2012) menyatakan bahawa modal insan merupakan aset yang paling bernilai kepada sesebuah negara malah memainkan peranan yang signifikan kepada pengekalan kompetitif dan kelangsungan negara. Modal insan perlu diuruskan dengan sempurna supaya mereka mampu memberi manfaat kepada organisasi dengan berkhidmat sebagai tenaga kerja yang berwibawa dan berkualiti. Demi melahirkan modal insan kelas pertama yang mempunyai daya saing, bertindak efektif, cekap dan fleksibel, aspek-aspek kemahiran insaniah perlu ditekankan serta diterapkan kepada golongan mahasiswa supaya mereka bersedia menghadapi cabaran ketika melangkah ke dunia pekerjaan (Ahmad Anuar \& Esa, 2010).

Walaupun terdapat pelbagai kajian penguasaan kemahiran insaniah pelajar telah dijalankan, namun kajian penguasaan khususnya kepada graduan di Malaysia adalah rendah. Kajian Sarkar, Overton, Thompson dan Rayner (2016) mengatakan terdapat ketidakserasian (mismatch) kemahiran yang diperlukan majikan dengan kemahiran yang dipunyai oleh pemohon. Majikan melaporkan bahawa tahap pemahaman pemohon terhadap perniagaan, pengalaman bekerja dan pengendalian makmal adalah tidak memuaskan. Hasil kajian beliau mendapati majikan tidak berpuas hati dengan tahap pemahaman dan kemahiran graduan aliran sains dalam kesedaran komersial (commercial awareness), pembelajaran secara berdikari (independent learning ability), kemahiran penyelesaian masalah (problem solving skills), kemahiran kepimpinan (leadership skills), dan keupayaan untuk menggunakan inisiatif sendiri (ability to use own initiative).

Demaria, Hodgson dan Czech (2018) mencadangkan kemahiran boleh-pindah (transferable skills) perlu diterapkan kepada pelajar tahun akhir untuk meningkatkan kebolehpasaran graduan. Hal ini adalah ekoran dari hasil kajiannya yang mendapati pelajar tahun akhir dalam bidang Sains Biomedikal mementingkan kemahiran boleh-pindah dari kemahiran teknikal, dan menilai kemahiran berkomunikasi sebagai kemahiran penting dalam prospek kerjaya. Selain itu, kajian Flynn, Ho, Vieira, Pittia dan Rosa (2017) pula mendapati persepsi pelajar Sains Makanan dan Teknologi terhadap penguasaan kemahiran insaniah dan kemahiran teknikal kendiri berada pada tahap yang memuaskan. Sektor makanan dan minuman pada masa akan datang memerlukan pekerja yang mempunyai kompetensi dari segi kemahiran insaniah dan teknikal, justeru kajian penilaian kendiri pelajar dapat membantu meningkatkan tahap pemahaman serta memperbaiki kekuatan dan kelemahan yang dihadapi.

Selaras dengan itu, Kementerian Pengajian Tinggi Malaysia telah memperkenalkan pendekatan penguasaan kemahiran insaniah mahasiswa yang menyeluruh di mana ia merangkumi aspek-aspek kemahiran generik yang melibatkan elemen kognitif, kepimpinan, berpasukan, komunikasi, dan pembelajaran berterusan. Tujuh kemahiran insaniah yang digariskan tersebut adalah kemahiran berkomunikasi, kemahiran kritis dan penyelesaian masalah, kemahiran berpasukan, pembelajaran berterusan dan pengurusan maklumat, kemahiran keusahawanan, etika dan moral profesional, serta kemahiran kepimpinan. Pada 
masa yang sama, pendekatan penguasaan kemahiran insaniah ini juga bertujuan untuk melengkapkan para mahasiswa dalam menghadapi perubahan ketara dalam persekitaran kerjaya justeru berupaya bersaing dalam dunia sebenar (Noor Lela Ahmad \& Suraini, 2016).

Bertitik tolak dari sudut perhubungan awam, kajian ini mengadaptasikan Teori Situasi dalam Penyelesaian Masalah (Situational Theory of Problem Solving) atau diringkaskan sebagai STOPS. Teori STOPS diasaskan oleh Kim dan Grunig (2011) yang bertindak sebagai rangka kerja untuk memahami persepsi publik dalam tingkah laku komunikasi terhadap sesuatu masalah. Dalam kajian ini, publik merujuk kepada graduan dan masalah merujuk kepada isu penguasaan kemahiran insaniah graduan. STOPS dibangunkan berpandukan Teori Situasi Publik (STP) yang diperkenalkan oleh Grunig pada tahun 1966. STP telah dirangka dengan tujuan mengenalpasti pelbagai kumpulan publik untuk meramal tingkah laku maklumat mereka dan mengurus pandangan awam secara efektif. Selain itu, STP memfokus kepada hasil komunikatif dalam pencarian dan pemprosesan maklumat, manakala STOPS pula mengembangkan teori itu merangkumi tingkah laku pemerolehan dan pemilihan maklumat. Malah Kim dan Grunig turut menambah konsep pembuatan keputusan dalam penyelesaian masalah.

\section{Teori Situasi Publik}

Pelopor Teori Situasi Publik (STP), James E. Grunig menyatakan STP telah menjelaskan bila dan mengapa individu menjadi aktif dalam tingkah laku komunikasi seperti pencarian maklumat. Jin (2007) berpendapat publik dianggap pasif apabila mereka memproses maklumat yang hadir secara rawak tanpa sebarang usaha, manakala publik aktif pula merupakan publik yang mencari maklumat tambahan. Teori ini dibangunkan sebagai teori tingkah laku komunikasi individu dalam membuat keputusan dan kemudiannya berpindah ke peringkat analisis kolektif sebagai konsep-konsep dalam teori peringkat individu yang digunakan untuk menerangkan dan mengenal pasti publik organisasi sebagai istilah yang digunakan dalam perhubungan awam (Grunig, 1997).

Secara amnya, STP seperti yang ditunjukkan dalam Rajah 1 mengandungi tiga pemboleh ubah yang menerangkan dan meramalkan tingkah laku komunikasi (Pengenalpastian Masalah, Pengenalpastian Kekangan, dan Tahap Penglibatan) serta dua pemboleh ubah terikat (Pencarian Maklumat dan Pemprosesan Maklumat) yang bertujuan menerangkan sesuatu kegiatan aktif dan pasif tingkah laku komunikasi dalam memperolehi maklumat (Kim \& Grunig, 2011). Seseorang yang merasa mempunyai masalah yang berkaitan dengan dirinya dan melihat halangan-halangan yang wujud untuk melakukan sesuatu berkenaan masalah tersebut, berkemungkinan akan mendapatkan dan memproses maklumat mengenainya. Ini adalah kerana teori situasi mempunyai kebolehan untuk menerangkan dan meramalkan kegiatan seseorang berkomunikasi secara aktif dalam hal-hal berkaitan sosial atau individu, malahan ia telah digunakan secara meluas oleh penyelidik serta pengamal perhubungan awam. 


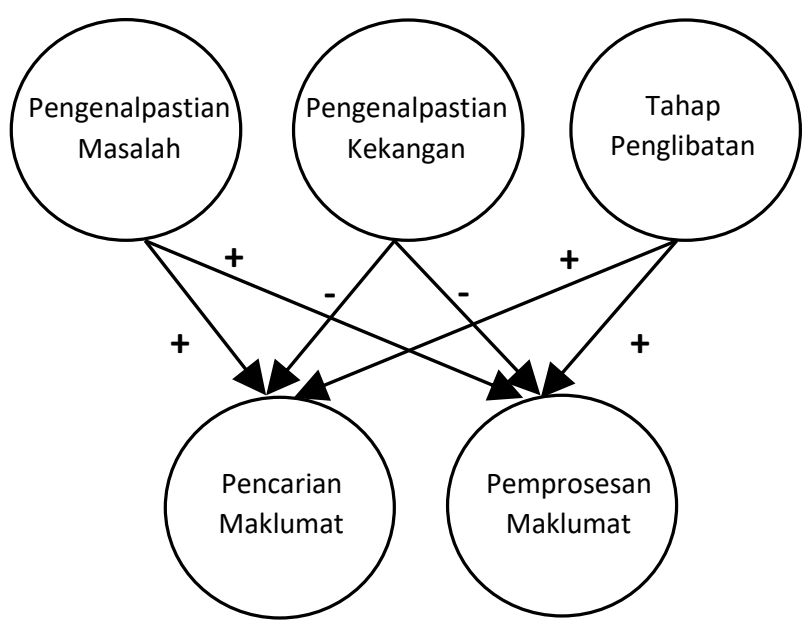

Rajah 1: Teori Situasi Publik (STP)

\section{Teori Situasi dalam Penyelesaian Masalah}

Secara amnya, Teori Situasi dalam Penyelesaian Masalah (STOPS) merupakan teori yang dikembangkan melalui teori klasik Grunig iaitu Teori Situasi Publik (STP). STOPS telah dibangunkan pada tahun 2006 untuk memperbaiki dan melanjutkan kebaikan STP (Kim, 2006). Penghasilan STOPS menjadikan teori ini lebih umum memerihalkan tentang tingkah laku komunikasi individu dalam proses penyelesaian masalah. Kim dan Grunig (2011) mentakrifkan "masalah" kerana terdapat jurang persepsi (perceptual discrepancy) antara keadaan yang dijangka (expected) dan keadaan yang dialami (experienced) dalam sesuatu situasi yang menghasilkan keadaan yang tidak selesa. Justeru itu, jelasnya "penyelesaian masalah" adalah satu usaha untuk mengurangkan jurang ini (perceived discrepancy) (Norliana, Chang, \& Mat Pauzi, 2016).

Kerangka model STOPS ditunjukkan dalam Rajah 2. Kim dan Grunig (2011) meneroka kaedah penyelesaian masalah dalam tiga peringkat. Peringkat pertama adalah membincangkan latar belakang situasi atau anteseden-anteseden perseptual kepada tindakan komunikatif dalam penyelesaian masalah, peringkat kedua adalah motivasi situasi dalam penyelesaian masalah (SMIPS), dan peringkat ketiga adalah tingkah laku komunikasi dalam penyelesaian masalah (CAPS). Pemboleh ubah-pemboleh ubah bebas pengenalpastian masalah, pengenalpastian kekangan dan pengenalpastian penglibatan mampu meningkatkan motivasi seseorang untuk menyelesaikan masalah yang akan mempengaruhi keaktifan seseorang dalam tingkah laku maklumat. 


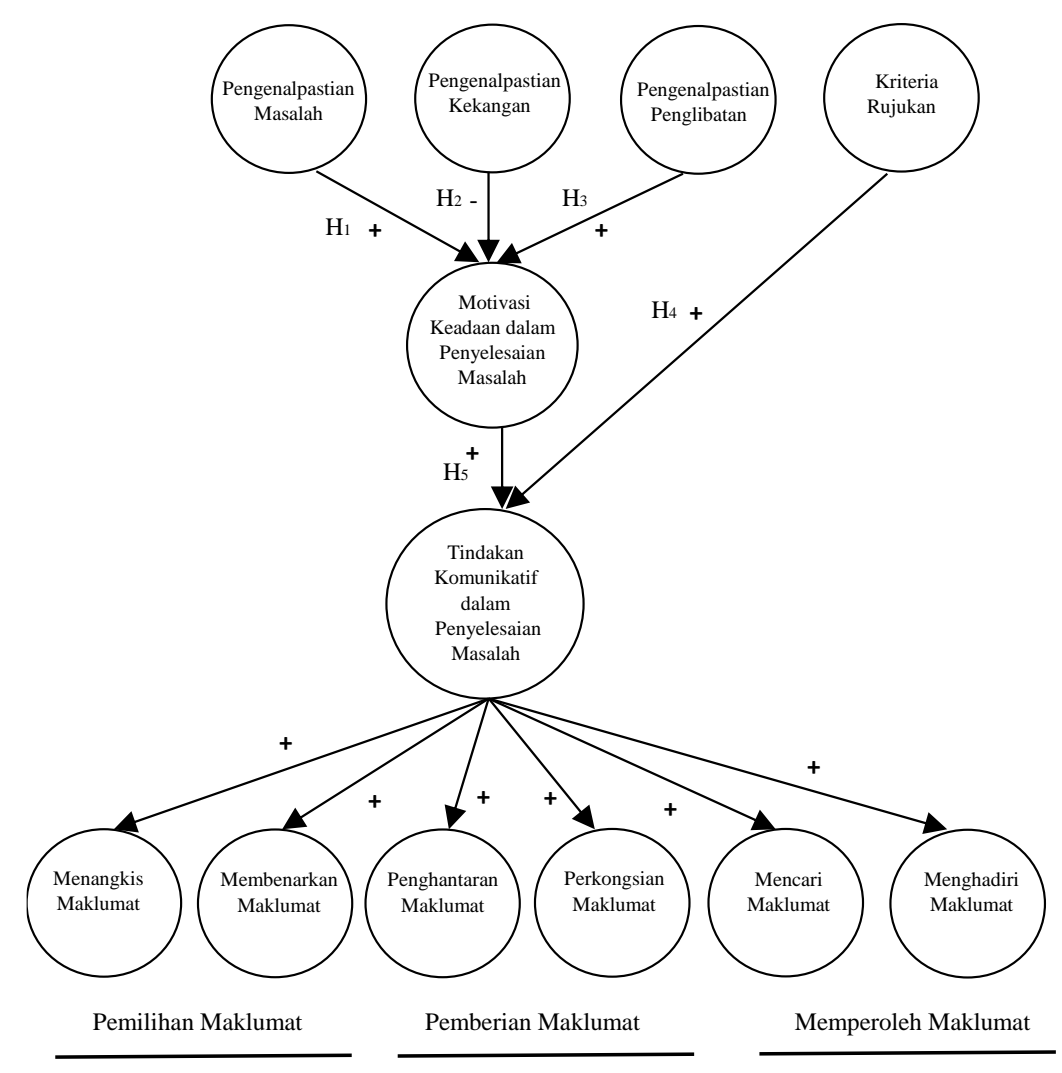

Rajah 2: Teori Situasi dalam Penyelesaian Masalah (STOPS)

\section{Anteseden-Anteseden Perseptif dan Kognitif kepada Tingkah Laku Komunikatif}

Menurut kompleks persepsi-motivasi-komunikasi, STOPS mencadangkan tiga pemboleh ubah persepsi (Pengenalpastian Masalah, Pengenalpastian Kekangan dan Pengenalpastian Penglibatan) serta satu pemboleh ubah kognitif (Kriteria Rujukan) yang membawa kepada tingkah laku komunikatif. Pengenalpastian Masalah merujuk seseorang individu memasuki situasi yang bermasalah ketika dia mampu mengenalpasti masalah tetapi tidak menemui penyelesaian yang sesuai. Oleh itu Kim dan Grunig (2011) mendefinisikan pengenalpastian masalah sebagai 'persepsi seseorang individu bahawa terdapat sesuatu yang hilang dan tidak mempunyai kaedah penyelesaian segera'.

Pengenalpastian Kekangan pula didefinisikan sebagai halangan dalam situasi yang membataskan keupayaan individu untuk menyelesaikan masalah (Grunig, 1997). Kim dan Grunig (2011) mengekalkan definisi asal pengenalpastian kekangan iaitu individu merasakan bahawa terdapat halangan dalam situasi yang mengehadkan kemampuan mereka untuk melakukan sebarang aktiviti terhadap keadaan itu.

Pengenalpastian Penglibatan merujuk kepada hubungan tanggapan yang dirasai oleh seseorang individu dalam situasi bermasalah. Tanggapan bahawa seseorang merasakan hubungannya dengan masalah mungkin tidak sesuai dengan hubungan sebenar yang dihadapi. Oleh itu, pemboleh ubah yang mencetuskan tindakan komunikatif individu ini dilabel sebagai hubungan yang dirasakan di antara diri dan masalah yang dihadapi.

Pemboleh ubah Kriteria Rujukan pula didefinisikan sebagai pengetahuan atau sistem penilaian subjektif yang mempengaruhi pendekatan seseorang dalam penyelesaian masalah (Kim \& Grunig, 2011). Pembolehubah ini asalnya pernah disingkirkan dari STP kerana ia terbukti lebih memberikan kesan komunikasi daripada sebab. Namun, ia kemudiannya diperkenalkan semula dalam STOPS. Kriteria Rujukan bertindak sebagai garis panduan untuk 
mencari jalan penyelesaian dan harus mencetuskan tindakan komunikatif. Walaupun begitu, perbezaan antara Kriteria Rujukan dengan tiga anteseden tersebut adalah CAPS tidak mempengaruhi motivasi untuk menyelesaikan masalah (Kim \& Krishna, 2014).

\section{Motivasi Situasi dalam Penyelesaian Masalah (SMIPS)}

Kim dan Grunig (2011) menambah komponen Motivasi Situasi dalam Penyelesaian Masalah dalam teori STOPS untuk mengkaji sama ada kehadiran faktor motivasi akan menjadi pengantara kepada hubungan antara pemboleh ubah persepsi, pemboleh ubah situasi dan tindakan komunikatif terhadap penyelesaian masalah. Secara khususnya, Kim dan Grunig (2011) mendefiniskan Motivasi sebagai keadaaan yang mana kesediaan epistemik dan kognitif berdasarkan situasi tertentu dalam usaha penyelesaian masalah. Pemboleh ubah ini membuatkan individu berhenti dan berfikir tentang masalah dan lebih ingin tahu tentang situasi masalah.

Konsep motivasi situasi ini adalah berbeza daripada motivasi komunikatif bukan situasi seperti keseronokan, melarikan diri, matlamat interpersonal, atau keperluan untuk interaksi sosial (Graham, Barbato \& Perse, 1993). la merupakan pemboleh ubah yang mampu memberi kesimpulan tentang pemboleh ubah perseptual dalam satu pernyataan konseptual tunggal. Motivasi situasi akan meningkat apabila seseorang individu merasakan sesuatu situasi masalah, hubungannya dengan masalah tersebut, dan kekurangan kekangan dalam melakukan sesuatu mengenainya.

\section{Tingkah Laku Komunikasi dalam Penyelesaian Masalah (CAPS)}

STOPS mengandungi enam pemboleh ubah komunikasi dalam tiga dimensi tingkah laku komunikasi yakni pemerolehan maklumat, pemilihan maklumat, dan pemberian maklumat. Enam pemboleh ubah tersebut adalah pencarian maklumat (aktif) dan pemerhatian maklumat (pasif) dalam dimensi memperoleh maklumat, penangkisan maklumat (aktif) dan pembenaran maklumat (pasif) dalam dimensi pemilihan maklumat, dan penyebaran maklumat (aktif) dan perkongsian maklumat (pasif) dalam dimensi pemberian maklumat. Menurut Kim dan Grunig (2011), usaha penyelesaian masalah yang lebih besar mampu meningkatkan tingkah laku maklumat dalam ketiga-tiga dimensi. Tingkah Laku Komunikasi merupakan komponen penting dalam STOPS yang menyediakan satu set pemboleh ubah endogen untuk diambil kira. Setiap dimensi memegang beberapa ciri unik keaktifan komunikatif, yang mana dimiliki oleh seseorang apabila menghadapi situasi yang bermasalah. Andaian CAPS ialah kita menggunakan tingkah laku komunikasi untuk menghadapi situasi bermasalah. Justeru itu, untuk menyesuaikan diri ke dalam persekitaran stabil, tingkah laku komunikasi menjadi satu cara hidup untuk seseorang individu melakukan sesuatu.

\section{Pemerolehan Maklumat}

Pemerolehan maklumat terdiri daripada subfaktor pencarian maklumat (information seeking) dan pemerhatian maklumat (information attending) di mana kedua-duanya berasal dari Teori Situasi Publik (STP). Pencarian maklumat mewakili tingkah laku komunikasi aktif yang merupakan pencarian bertujuan kepada maklumat dalam topik yang khusus (Grunig, 1997). Sebaliknya, pemerhatian maklumat pula merujuk kepada tingkah laku komunikasi pasif, di mana merupakan sebuah penemuan secara kebetulan dan terus diikuti dengan pemprosesan maklumat itu (Clarke \& Kline, 1974). Sebagai contoh, sebagai pencari maklumat aktif, seseorang individu aktif mencari maklumat mengenai isu penguasaan kemahiran insaniah 
melalui pelbagai medium seperti di laman web, makalah, berita, dan perpustakaan. Sebaliknya bagi pemerhatian maklumat pasif, individu hanya mendapatkan maklumat secara tidak langsung atau secara kebetulan sahaja seperti di television atau radio. Walaupun begitu, cerapan maklumat yang diterima berlaku tanpa usaha yang aktif oleh individu tersebut. Individu yang terlibat secara aktif mempunyai kebarangkalian yang lebih tinggi untuk turut serta dalam pemerolehan maklumat secara aktif dan pasif. Namun sekiranya individu mempunyai persepsi permasalahan yang rendah mungkin hanya terlibat dengan pemerhatian maklumat sahaja.

\section{Pemilihan Maklumat}

Penangkisan maklumat (information forefending) dan pembenaran maklumat (information permitting) merupakan dua subfaktor yang tergolong dalam dimensi pemilihan maklumat. Pemilihan maklumat didefinisikan sebagai komponen kognitif dalam penggunaan maklumat. Penangkisan maklumat bersifat aktif manakala pembenaran maklumat bersifat pasif. Penangkisan maklumat bertindak sebagai penapisan yang aktif terhadap maklumat yang dianggap tidak relevan atau tidak berguna kepada individu dan hasilnya maklumat menjadi lebih spesifik dan sistematik dalam membantu individu menyelesaikan masalah (Kim \& Grunig, 2011). Apabila individu mengambil pendekatan pasif untuk menguruskan maklumat yang diperoleh dengan menerimanya, dia terlibat dalam situasi pembenaran maklumat. Pembenaran maklumat berlaku pada tahap awal penyelesaian masalah kerana individu cenderung mempertimbangkan semua maklumat yang mungkin membantu dalam penyelesaian masalah sebelum memulakan proses pemilihan (Kim, Ni, Kim, \& Kim, 2012). Walau bagaimanapun, setelah individu memperoleh maklumat yang mencukupi, proses penyingkiran maklumat bermula secara sistematik.

\section{Pemberian Maklumat}

Dimensi pemberian maklumat terdiri daripada subfaktor penyebaran maklumat (information forwarding) dan perkongsian maklumat (information sharing). Pemberian maklumat pasif merujuk kepada perkongsian maklumat reaktif yang tidak dirancang, maklumat hanya disebarkan apabila sebuah pendapat atau kepakaran dikehendaki oleh orang lain. Sebaliknya, pemberian maklumat yang aktif akan memberi maklumat secara proaktif ataupun secara suka rela tanpa mengira siapa yang memintanya. Kim dan Grunig (2011) berpendapat pada peringkat awal penyelesaian masalah, individu disangkakan memberi maklumat sebagai kaedah pengumpulan maklumat. Seterusnya pada peringkat berikut, penglibatan dalam penyebaran maklumat adalah berkaitan dengan kewujudan persepsi permasalahan yang serupa kepada orang lain.

\section{Kajian-Kajian Lepas STOPS}

STOPS telah digunakan dalam penyelidikan-penyelidikan yang berkaitan dengan konsep 'publik' merentasi bidang (Kim \& Ni, 2013). Misalnya, STOPS telah digunakan dalam kajian bidang komunikasi kesihatan seperti kajian siber oleh (Kim \& Vibber, 2012). Mereka telah menjalankan penyelidikan yang mengkaji keefektifan ruang siber dalam menangani masalah kesihatan kronik. Kajian tersebut mengukur situasi di mana komunikasi dalam talian mampu membantu dan meningkatkan keupayaan seseorang menyelesaikan masalah kesihatan. Perkara utama yang difokuskan dalam kajian adalah hasil penggunaan internet, kepadatan hubungan, meningkatkan rangkaian hubungan dan kegemaran untuk bergaul. Hasil kajian mendapati pesakit yang menghidap penyakit kronik seperti lumpuh, kencing manis, kanser, 
kemurungan, dan HIV/AIDS mendapat manfaat daripada hasil interaksi dalam talian dengan pesakit lain. Ini membawa kepada kesimpulan kajian yang menunjukkan para pesakit membentuk hubungan dalam talian yang mampu meningkatkan pengalaman hubungan serta meningkatkan hasil untuk menangani penyakit secara psikologi dan fizikal (Kim \& Vibber, 2012).

Penyelidikan dalam pendermaan organ dan darah oleh Kim, Shen dan Morgan (2011) turut melihat penggunaan STOPS yang mengkaji kuasa ramalan. Mereka meneliti niat publik untuk mendaftar sebagai penderma organ di mana ia yang merupakan pemboleh ubah dalam tingkah laku komunikasi aktif dalam kajian tersebut. Tambahan lagi, kajian ini memperkenalkan konsep masalah sebagai kesan rantaian pengiktirafan, iaitu adakah seseorang itu akan menjadi aktif mengenai isu seperti isu derma organ jika didedahkan dengan informasi berkaitan. Hasil kajian mendapati pemboleh ubah persepsi dan motivasi dalam STOPS mampu meramalkan tingkah laku komunikasi yang aktif dan niat untuk bertingkah laku mempunyai kaitan dengan sumbangan pada masa hadapan.

Jalil (2014) telah menggunakan STOPS untuk mengkaji persepsi publik terhadap perbuatan merokok dengan menggunakan agama sebagai faktor nilai tambah kepada kajiannya. Hasil dapatan dalam kajian beliau menyatakan faktor agama mempunyai kepentingan yang signifikan dalam pengenalpastian masalah dan pengenalpastian penglibatan. Norliana (2017) pula menggunakan STOPS untuk mengkaji kebolehdapatan pekerjaan graduan di Universiti Kebangsaan Malaysia dan menghubungkaitkan komitmen organisasi dalam penyelidikan doktor falsafah beliau.

Kajian STOPS seterusnya adalah mengenai pembentukkan sekumpulan publik yang dilabel sebagai publik 'lacuna' di mana terma 'lacuna' ini membawa maksud 'jurang' oleh Krishna (2017). Publik lacuna merupakan publik yang memegang nilai negativiti yang tinggi terhadap sesuatu isu, mempunyai pengetahuan yang cetek mengenai sesuatu isu yang spesifik, dan bermotivasi tinggi terhadap tingkah laku informasi terhadap isu tersebut. Kajian beliau memberi tumpuan kepada isu keselamatan vaksin di Amerika Syarikat di mana publik lacuna diuji dengan kesedaran mengenai vaksin tersebut. Hasil kajian mendapati bahawa individu yang kurang pengetahuan dan memegang negativiti mempamerkan kecenderungan yang tinggi dalam persepsi, motivasi dan tingkah laku komunikasi aktif terhadap vaksin. Ini menunjukkan kajian beliau menyokong pernyataan bahawa pembentukkan publik lacuna sebagai kumpulan publik kurang berpengetahuan yang bersikap negatif terhadap sesuatu isu.

Selain itu, kajian STOPS juga dapat menguji dan memberi sokongan dalam menjelaskan tindakan komunikatif. Kim dan Grunig (2011) telah menjalankan dua kajian menggunakan soal selidik terhadap masalah individu dan sosial seperti perang di Iraq, kehilangan berat badan, dan menghilangkan tindakan afirmatif dalam pendidikan tinggi Amerika. Dalam dua kajian mereka terhadap masalah kesihatan yang berkaitan dengan penjualan organ di negara-negara miskin dan menilai kematian sel otak untuk penderma organ, ia telah menyokong hubungan hipotesis teori ini. Secara signifikannya lebih besar situasi pengenalpastian masalah seseorang, lebih besar motivasi dalam situasi penyelesaian masalah dan lebih besar pengenalpastian kekangan akan menurunkan tahap motivasi dalam situasi penyelesaian masalah seseorang. Sebaliknya semakin besar pengenalpastian penglibatan akan menyebabkan lebih tinggi tahap motivasi dalam situasi penyelesaian masalah seseorang. 


\section{METODOLOGI KAJIAN}

Kajian berbentuk kuantitatif ini dijalankan dengan menggunakan kaedah banci dalam talian yang disokong oleh laman web SurveyMonkey (https://www.surveymonkey.com). Laman ini bertindak sebagai alat dalam pengedaran borang soal selidik kepada responden untuk mendapatkan maklum balas terhadap isu penguasaan kemahiran insaniah. Pautan borang soal selidik dihantar menerusi mel elektronik kepada 7,047 orang graduan UKM yang telah menamatkan pengajian pada tahun 2018 . Sebanyak 1,007 borang jawapan telah diterima dan setelah melaksanakan proses pembersihan data, didapati hanya 674 borang jawapan diisi secara lengkap iaitu 254 daripada graduan siswazah, 415 daripada graduan prasiswazah dan baki 5 daripada graduan diploma. Oleh yang demikian, kajian ini yang memfokus kepada penguasaan kemahiran insaniah graduan prasiswazah menggunakan 415 borang jawapan sahaja.

\section{Instrumen Kajian}

Borang soal selidik yang digunakan dalam kajian ini dibangunkan menerusi adaptasi teori Situasi dalam Penyelesaian Masalah yang dikemukakan oleh Kim dan Grunig (2011). la mengandungi empat bahagian berbeza yang menguji persepsi graduan terhadap isu penguasaan kemahiran insaniah. Secara spesifiknya, bahagian A mengandungi soalan-soalan berkaitan dengan latar belakang atau demografi responden seperti jantina, bangsa, tahun pengajian dan status pekerjaan manakala Bahagian B pula menganalisa pemboleh ubah persepsi penguasaan kemahiran insaniah kendiri graduan. Bahagian $\mathrm{C}$ mengandungi soalan berkaitan pemboleh ubah tingkah laku komunikasi dalam penyelesaian masalah (CAPS) dan seterusnya Bahagian D menganalisa pemboleh ubah teori Situasi dalam Penyelesaian Masalah (STOPS). Skala pengukuran thurstone digunakan dalam borang soal selidik iaitu daripada $0=$ tidak setuju sama sekali sehingga $10=$ setuju sepenuhnya untuk menunjukkan sejauh mana tahap persetujuan responden terhadap setiap item yang disenaraikan.

\section{Analisis Data}

Data yang diperoleh dianalisis menggunakan statistik deskriptif untuk meneliti profil responden, seterusnya analisis faktor pengesahan (CFA) dan analisis model persamaan struktural (SEM) dijalankan dengan bantuan perisian IBM-SPSS versi 21 dan IBM-SPSS-AMOS. Berdasarkan bilangan responden $(\mathrm{N}=415)$ dengan data yang lengkap, saiz sampel ini adalah mencukupi bagi pengujian SEM (Hair, J. F., Black, W. C., Babin, B. J., \& Anderson, 2010). Menurut Byrne (2010) pula, tujuan analisis CFA adalah untuk menentukan bilangan item yang dimasukkan ke dalam konstruk selari dengan apa yang dinyatakan dalam teori. Terdapat beberapa petunjuk kesepadanan indeks telah dicadangkan untuk menguji model yang dihipotesiskan dan penilaian kesepadanan model adalah tertakluk kepada pelbagai kriteria termasuk kesesuaian mutlak dan kesepadanan relatif. Walau bagaimanapun, tidak ada persetujuan terhadap indeks kesepadanan yang universal untuk diikuti. Hair et al. (2010) mencadangkan sekurang-kurangnya satu indeks kesepadanan dirujuk dari setiap kategori kesepadanan model. Tiga kategori indeks kesepadanan model tersebut adalah Absolute Fit, Incremental Fit, dan Parsimonious Fit. Kajian ini menggunakan indeks root mean square error of approximation (RMSEA) bagi kategori Absolute Fit, comparative fit index (CFI) bagi kategori Incremental Fit, dan Chi-Square/df bagi kategori Parsimonious Fit.

Seterusnya, analisis SEM dijalankan untuk menguji model hipotesis peramal latar belakang situasi. la bertujuan melihat kesepadanan subjek kajian iaitu pengenalpastian hubungan di antara kesemua pemboleh ubah dalam model teori tersebut. Selanjutnya 
analisis SEM turut digunakan untuk membentuk model alternatif atau dikenali sebagai model modifikasi sekiranya diperlukan dengan mencadangkan perhubungan baru antara kesemua pemboleh ubah melalui petunjuk indeks modifikasi.

\section{Analisis Deskriptif}

\section{DAPATAN KAJIAN DAN PERBINCANGAN}

Secara keseluruhannya, profil demografi responden ditunjukkan dalam Jadual 1 . Responden perempuan mencatatkan peratusan yang tertinggi iaitu 75.4 peratus (313 orang) manakala responden lelaki adalah sebanyak 24.6 peratus (102 orang). Majoriti responden terdiri daripada graduan Melayu di mana ia mencatatkan sebanyak 81.2 peratus (337 orang) berbanding graduan yang berasal daripada etnik-etnik yang lain iaitu Cina (9.2 peratus), Bumiputera Sabah/Sarawak (5.1 peratus), India (3.9 peratus) dan lain-lain (0.7 peratus). Hasil kajian juga mendapati responden yang berasal dari negeri Selangor mencatatkan peratusan yang tertinggi iaitu sebanyak 15.6 peratus, diikuti responden dari negeri Kedah (10.4 peratus) dan negeri Johor (9.6 peratus). Responden yang berasal dari negeri Sarawak, Pulau Pinang, Sabah dan Perlis pula mencatatkan peratusan yang kecil iaitu masing-masing pada 3.6 peratus, 3.1 peratus, 2.4 peratus, dan 0.7 peratus.

Berdasarkan pemboleh ubah fakulti, jumlah responden tertinggi yang mengambil bahagian dalam soal selidik ini datang daripada Fakulti Sains Kesihatan iaitu sebanyak 18.3 peratus diikuti oleh Fakulti Sains Sosial dan Kemanusiaan sebanyak 17.8 peratus dan Fakulti Ekonomi dan Pengurusan sebanyak 13.0 peratus. Bagi Fakulti Pendidikan, Fakulti UndangUndang, Fakulti Farmasi dan Fakulti Pergigian, masing-masing mencatatkan jumlah responden yang terendah iaitu hanya sebanyak 3.6 peratus, 2.9 peratus, 1.7 peratus dan 1.2 peratus.

Jadual 1: Profil responden

\begin{tabular}{lcc}
\hline Profil responden & Kekerapan & Peratus \\
\hline Jantina & 102 & 24.6 \\
Lelaki & 313 & 75.4 \\
Perempuan & Jumlah & $\mathbf{4 1 5}$ \\
& & \\
Keturunan & 337 & 81.2 \\
Melayu & 38 & 9.2 \\
Cina & 16 & 3.9 \\
India & 21 & 5.1 \\
Bumiputera Sabah/Sarawak & 3 & 0.7 \\
Lain-lain & Jumlah & $\mathbf{1 0 0}$ \\
& 415 & \\
Negeri kelahiran & & 9.6 \\
Johor & 40 & 10.4 \\
Kedah & 43 & 9.4 \\
Kelantan & 4.8 \\
Melaka & 39 & 4.1 \\
Negeri Sembilan & 3.5 \\
Pahang & 20 & 3.1 \\
Pulau Pinang & 17 & \\
\hline
\end{tabular}




\begin{tabular}{|c|c|c|c|}
\hline Perak & & 37 & 8.9 \\
\hline Perlis & & 3 & 0.7 \\
\hline Selangor & & 66 & 15.9 \\
\hline Terengganu & & 29 & 7.0 \\
\hline Sabah & & 10 & 2.4 \\
\hline Sarawak & & 15 & 3.6 \\
\hline Lain-lain & & 52 & 12.5 \\
\hline & Jumlah & 415 & 100 \\
\hline \multicolumn{4}{|l|}{ Fakulti Pengajian } \\
\hline Fakulti Ekonomi dan Perniagaan & & 54 & 13 \\
\hline Fakulti Farmasi & & 7 & 1.7 \\
\hline Fakulti Kejuruteraan dan Alam Bina & & 46 & 11.1 \\
\hline Fakulti Pendidikan & & 15 & 3.6 \\
\hline Fakulti Pengajian Islam & & 48 & 11.6 \\
\hline Fakulti Pergigian & & 5 & 1.2 \\
\hline Fakulti Perubatan & & 25 & 6.0 \\
\hline Fakulti Sains Kesihatan & & 76 & 18.3 \\
\hline Fakulti Sains dan Teknologi & & 30 & 7.2 \\
\hline Fakulti Sains Sosial dan Kemanusiaan & & 74 & 17.8 \\
\hline Fakulti Teknologi dan Sains Maklumat & & 23 & 5.5 \\
\hline \multirow[t]{2}{*}{ Fakulti Undang-undang } & & 12 & 2.9 \\
\hline & Jumlah & 415 & 100 \\
\hline
\end{tabular}

\section{Analisis Faktor Pengesahan (CFA) bagi Model Pengukuran STOPS}

Hair et al. (2010) mengemukakan bahawa sesuatu model dianggap memenuhi ciri-ciri model yang sesuai sekiranya ia mencapai sekurang-kurangnya satu indeks kesepadanan. Nilai yang dicadangkan bagi indeks kesepadanan RMSEA adalah kurang daripada 0.08, nilai CFI pula lebih daripada 0.90 dan nilai Chi-Square/df mestilah kurang daripada 5.0. Walau bagaimanapun, nilai indeks tersebut hanyalah sekadar cadangan yang diberikan oleh para penyelidik dalam kajian-kajian lepas dan nilai yang boleh diterima bergantung kepada literatur yang dirujuk (Zainudin, Lim \& Nur Fairuza, 2018)

Model pengukuran STOPS terdiri daripada empat pemboleh ubah eksogen iaitu Pengenalpastian Masalah, Pengenalpastian Kekangan, Pengenalpastian Penglibatan, Kriteria Rujukan serta satu pemboleh ubah endogen iaitu Motivasi dalam Situasi Penyelesaian Masalah dan masing-masing mengandungi empat item pengukuran. Namun, model ini perlu dimodifikasikan bagi memperbaiki indeks kesepadanan agar ia mewakili data sampel dengan lebih tepat. Proses modifikasi dilakukan dengan berpandukan petunjuk indeks modifikasi. Keputusannya, Sebanyak tujuh item telah dikorelasikan dengan suatu item yang lain, iaitu MI $\mathrm{e} 5 \leftrightarrow \mathrm{e} 6, \mathrm{e} 9 \leftrightarrow \mathrm{e} 10, \mathrm{e} 11 \leftrightarrow \mathrm{e} 12, \mathrm{e} 14 \leftrightarrow \mathrm{e} 16, \mathrm{e} 17 \leftrightarrow \mathrm{e} 19, \mathrm{e} 17 \leftrightarrow \mathrm{e} 20$, dan $\mathrm{e} 19 \leftrightarrow \mathrm{e} 20$. Proses modifikasi yang dijalankan ini mengambil cadangan yang dikemukakan oleh Hair et al. (2014) yang mengatakan jika terdapat korelasi yang tinggi antara dua item, ia boleh digabungkan untuk mendapatkan model padanan. Sebaliknya, jika item tidak disokong secara teori, berkorelasi, maka model perlu diubah suai dengan membuang item yang mempunyai muatan faktor yang lebih rendah daripada dua item.

Sejurus proses modifikasi dilaksanakan, hasil analisis menunjukkan The Root MeanSquare Error of Approximation (RMSEA) bagi model pengukuran STOPS adalah 0.091 di mana nilai tersebut masih boleh diterima sekiranya ia menghampiri nilai 0.80 dan kurang daripada 
1.0 (Zainudin et al., 2018). Nilai Comparative Fit Index (CFI) pula adalah 0.939 menunjukkan ia sepadan (fit) dengan nilai yang ditetapkan oleh (Bentler \& Bonett, 1980; Bentler, 1990) iaitu nilai adalah lebih daripada 0.90. Bagi nilai Chi Square/Degree of Freedom (ChiSq/df) nilai yang diperoleh adalah 4.414 iaitu tidak melebihi 5.0 seperti yang disarankan oleh Marsh \& Hocevar (1985). Secara umumnya model ini mencapai indeks kesepadanan yang baik dengan data kajian yang signifikan. Hasil analisis model pengukuran STOPS ditunjukkan dalam Rajah 3 dan keputusan CFA ditunjukkan dalam Jadual 2.

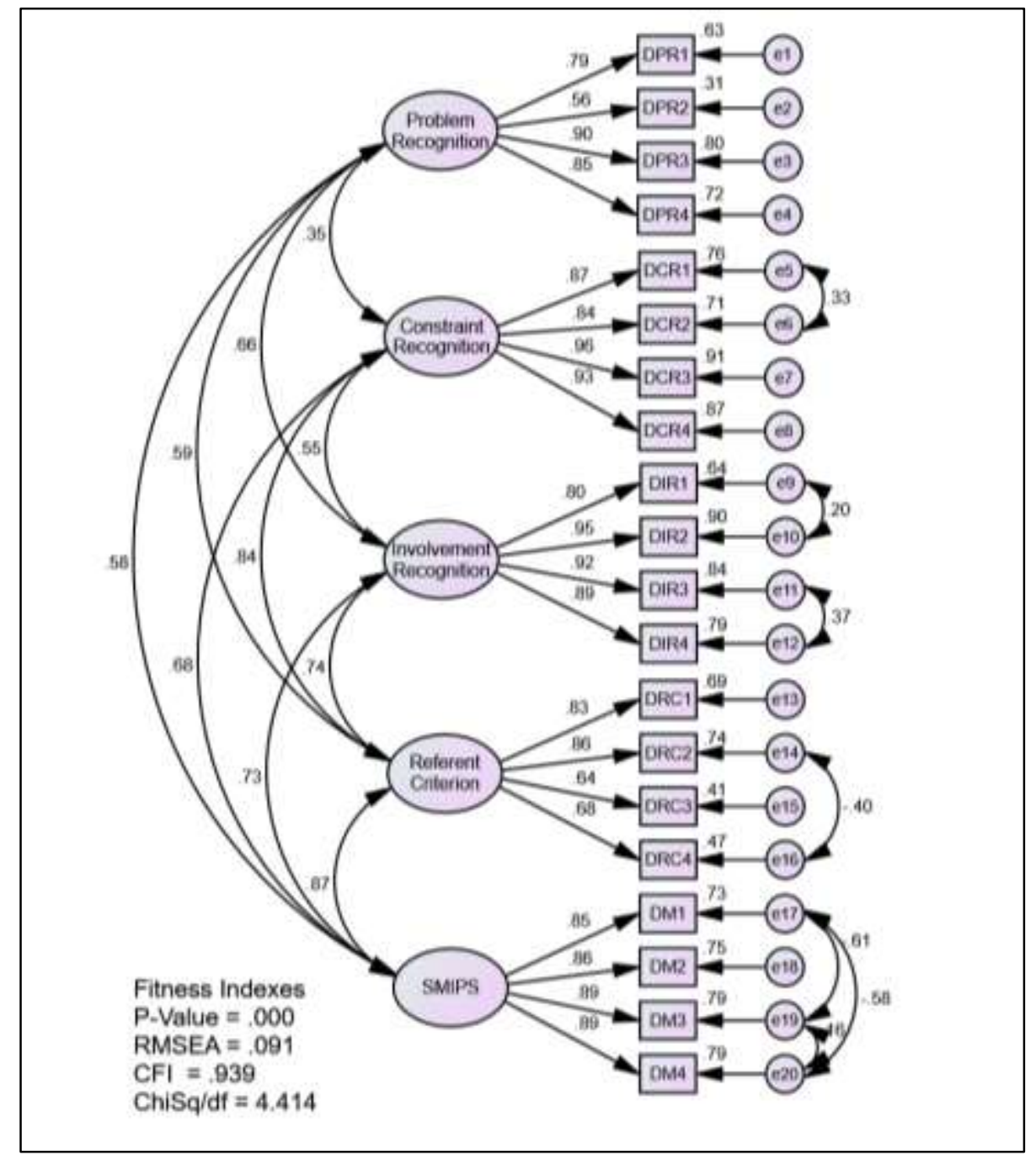

Rajah 3: Model CFA bagi STOPS

Jadual 2: Keputusan CFA bagi Model STOPS

\begin{tabular}{|c|c|c|c|c|}
\hline Konstruk & Item & Pemberat Faktor & CR (minimum 0.6) & AVE (minimum 0.5) \\
\hline \multicolumn{5}{|l|}{ Komponen } \\
\hline PR & DPR1 & 0.79 & 0.863 & 0.618 \\
\hline (Pengenalpastian & DPR2 & 0.56 & & \\
\hline \multirow[t]{2}{*}{ Msalah) } & DPR3 & 0.90 & & \\
\hline & DPR4 & 0.85 & & \\
\hline \multirow{4}{*}{$\begin{array}{c}\text { CR } \\
\text { (Pengenalpastian } \\
\text { Kekangan) }\end{array}$} & DCR1 & 0.87 & 0.945 & 0.812 \\
\hline & DCR2 & 0.84 & & \\
\hline & DCR3 & 0.96 & & \\
\hline & DCR4 & 0.93 & & \\
\hline
\end{tabular}




\begin{tabular}{|c|c|c|c|c|}
\hline IR & DIR1 & 0.80 & 0.939 & 0.795 \\
\hline (Pengenalpastian & DIR2 & 0.95 & & \\
\hline \multirow[t]{2}{*}{ Penglibatan) } & DIR3 & 0.92 & & \\
\hline & DIR4 & 0.89 & & \\
\hline RC & DRC1 & 0.83 & 0.842 & 0.575 \\
\hline \multirow[t]{3}{*}{ (Kriteria Rujukan) } & DRC2 & 0.86 & & \\
\hline & DRC3 & 0.64 & & \\
\hline & DRC4 & 0.68 & & \\
\hline $\mathbf{M}$ & DM1 & 0.85 & 0.927 & 0.762 \\
\hline (Motivasi dalam Situasi & $\mathrm{DM} 2$ & 0.86 & & \\
\hline \multirow[t]{2}{*}{ Penyelesaian Masalah) } & DM3 & 0.89 & & \\
\hline & DM4 & 0.89 & & \\
\hline
\end{tabular}

Dapatan kajian menunjukkan model STOPS mencapai ketepatan padanan yang baik serta mencapai kesahan konvergen berdasarkan hubungan yang signifikan bagi pemboleh ubah yang dinyatakan. Analisis CFA yang dijalankan telah membuktikan bahawa pengujian konstruk Pengenalpastian Masalah, Pengenalpastian Kekangan, Pengenalpastian Penglibatan, Kriteria Rujukan dan Motivasi dalam Situasi Penyelesaian Masalah adalah sah dan mewakili konstruk masing-masing.

Keputusan yang diperoleh dalam kajian ini turut menyokong hubungan hipotesis yang dikemukakan dalam model teori asal. Hipotesis yang dicadangkan adalah (H1) semakin tinggi Pengenalpastian Masalah, semakin tinggi Motivasi dalam situasi penyelesaian masalah, $(\mathrm{H} 2)$ semakin rendah Pengenalpastian Kekangan, semakin tinggi Motivasi dalam situasi penyelesaian masalah, (H3) semakin tinggi Pengenalpastian Penglibatan, semakin tinggi Motivasi dalam situasi penyelesaian masalah, $(\mathrm{H} 4)$ semakin tinggi Kriteria Rujukan, semakin tinggi Tingkah Laku Komunikasi dalam penyelesaian masalah, dan (H5) semakin tinggi Motivasi dalam situasi penyelesaian masalah, semakin tinggi Tingkah Laku Komunikasi dalam penyelesaian masalah. Model hipotesis teori ditunjukkan dalam Rajah 4.

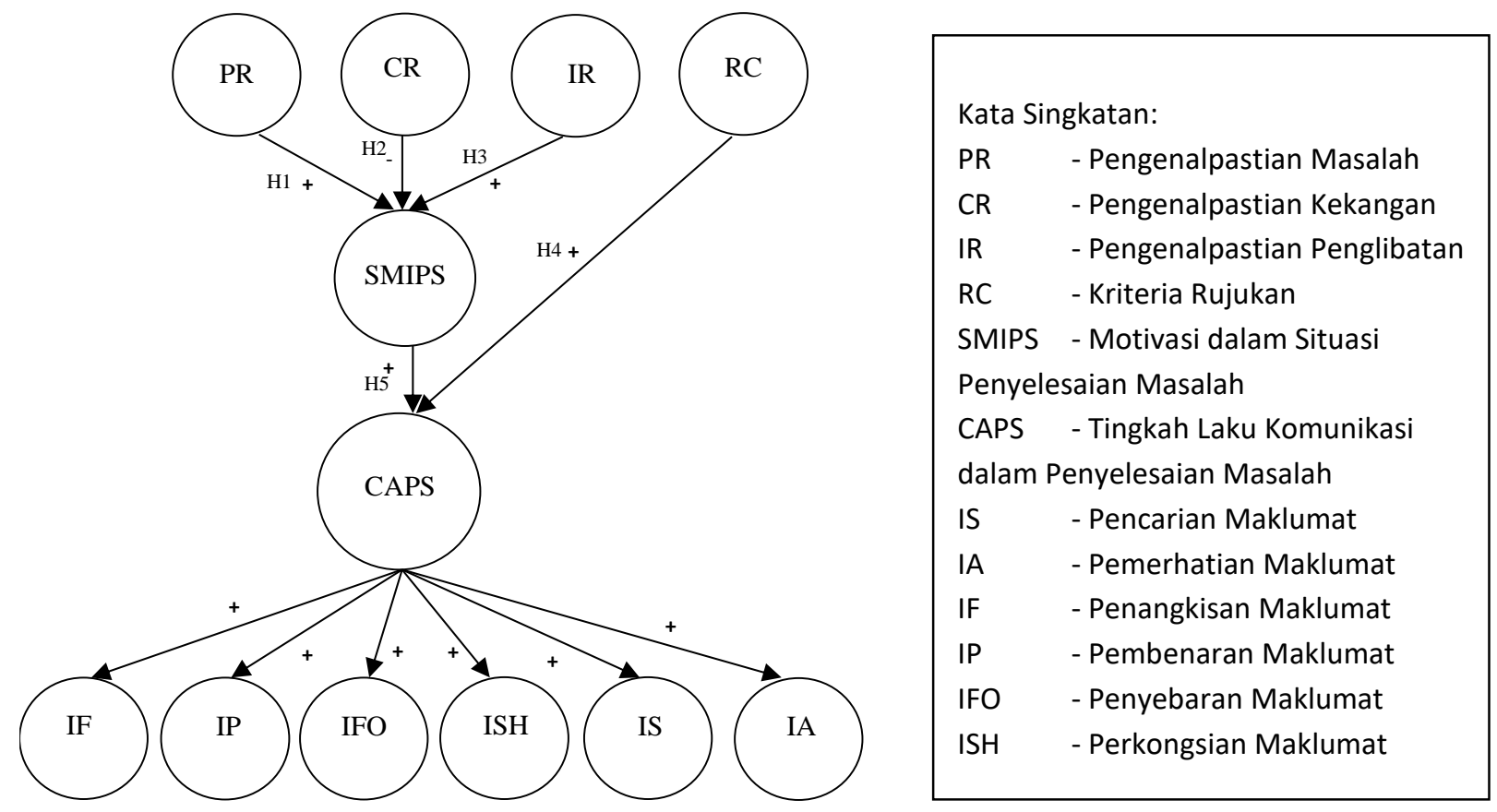

Rajah 4: Model Hipotesis STOPS 
Analisis SEM menunjukkan hubungan positif terhadap laluan pekali piawaian (coefficients path) di antara pemboleh ubah Pengenalpastian Masalah dan Pengenalpastian Penglibatan dengan pemboleh ubah Motivasi, dan hubungan negatif bagi pemboleh ubah Pengenalpastian Kekangan dengan pemboleh ubah Motivasi. Hasil analisis menunjukkan beta piawai 0.64 ( $p<0.001$ ) bagi hubungan Pengenalpastian Masalah dengan Motivasi dan beta piawai 0.32 ( $p<0.001$ ) bagi hubungan Pengenalpastian Penglibatan dengan Motivasi, justeru menyokong hipotesis $\mathrm{H} 1$ dan $\mathrm{H} 3$ yang mencadangkan hubungan yang positif antara pemboleh ubah tersebut. H2 pula mencadangkan hubungan negatif antara pemboleh ubah Pengenalpastian Kekangan dengan Motivasi dan keputusan analisis juga menyokong hipotesis ini dengan beta piawai $-0.06(p=0.085)$.

H4 mencadangkan hubungan positif terhadap pemboleh ubah Kriteria Rujukan dengan Tingkah Laku Komunikasi dalam Penyelesaian Masalah (CAPS) dan hasil analisis menunjukkan hipotesis disokong dengan beta piawai $0.60(p<0.001)$. H5 pula mencadangkan hubungan yang positif bagi pemboleh ubah Motivasi dengan CAPS dan hipotesis ini turut disokong dengan beta piawai $0.49(p<0.001)$. Hasil analisis ini secara langsung menunjukkan bahawa peningkatan motivasi graduan dalam menyelesaikan masalah isu penguasaan kemahiran insaniah adalah bergantung kepada inisiatif graduan tersebut untuk mentafsir penguasaan kemahiran insaniah sebagai satu masalah, melihat diri adalah terlibat dengan masalah tersebut dan juga perlu mengambil kira kekangan yang menghalang motivasi dalam mencari kaedah penyelesaian. Di samping itu, tahap keaktifan Tingkah Laku Komunikasi dalam penyelesaian masalah (CAPS) yang dikaji turut menunjukkan pengaruh positif daripada pemboleh ubah Kriteria Rujukan dan pemboleh ubah Motivasi. Keputusan model hipotesis STOPS ditunjukkan dalam Rajah 5.

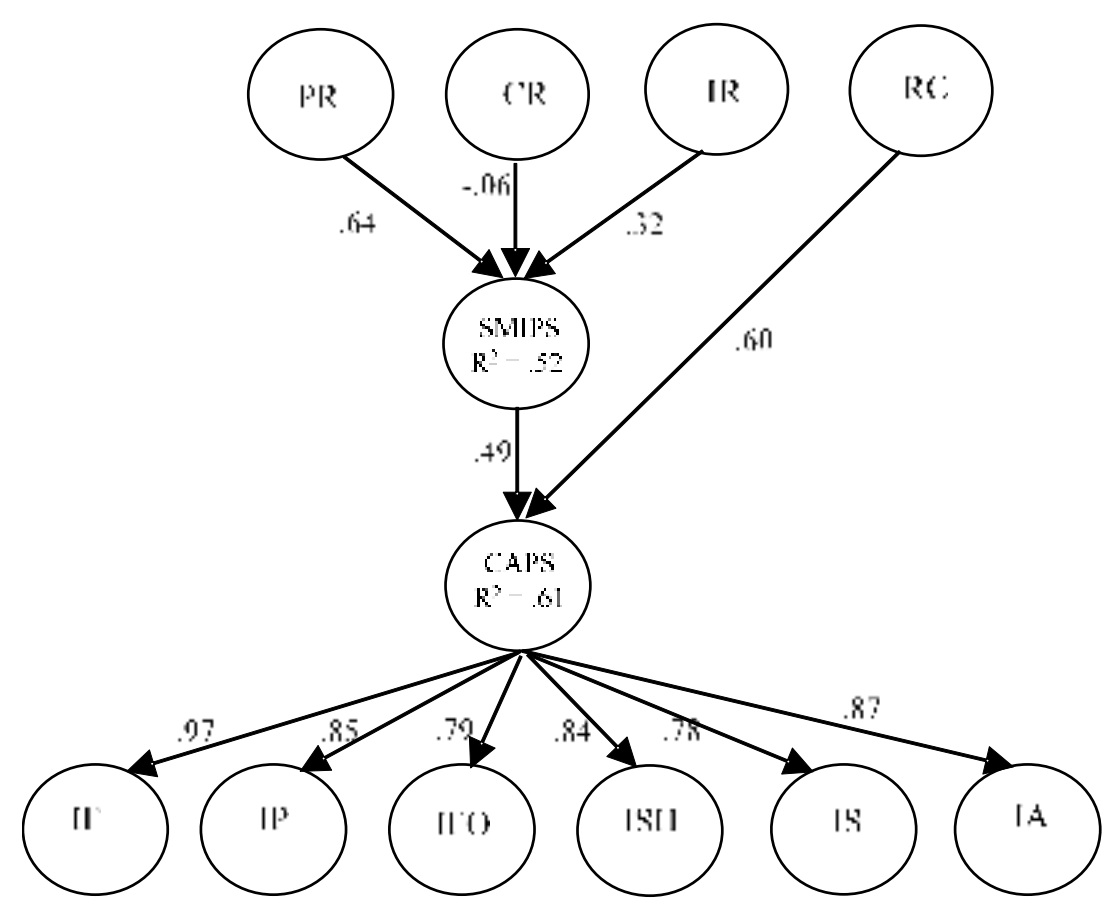

Rajah 5: Hasil Analisis SEM bagi Model STOPS 
Nilai koefisien penentuan $\mathrm{R}^{2}$ bertindak sebagai penentu sesebuah hubungan di antara pemboleh ubah sama ada ia bersifat kuat, sederhana, mahupun lemah. Cohen (1988) menyatakan bahawa nilai $\mathrm{R}^{2}=0.26$ dan ke atas menunjukkan hubungan yang teguh manakala Chin (1998) pula mengkategorikan hubungan yang lemah mempunyai nilai $\mathrm{R}^{2}=0.19$, hubungan yang sederhana mempunyai nilai $R^{2}=0.33$ dan hubungan yang kuat mempunyai nilai $R^{2}=0.67$. Berdasarkan Rajah 3, nilai kuasa dua berganda menunjukkan sumbangan pemboleh ubah Pengenalpastian Masalah, Pengenalpastian Kekangan, dan Pengenalpastian Penglibatan dalam menganggar atau menerangkan pemboleh ubah SMIPS ialah sebanyak $52 \%\left(R^{2}=0.52\right)$ dan terletak pada tahap sederhana kuat. Apabila isu penguasaan kemahiran insaniah dikenalpasti sebagai sesuatu masalah, pada tahap kekangan yang rendah dan tahap penglibatan yang tinggi dalam menyelesaikan masalah, graduan bercenderung untuk berhenti dan berfikir tentang cara untuk menyelesaikan masalah. Motivasi ini tercetus apabila graduan melihat isu penguasaan kemahiran insaniah sebagai masalah yang dihadapi secara peribadi dan terlibat secara langsung dengan kehadiran kekangan yang minimum untuk menyelesaikan masalah tersebut.

Bagi pemboleh ubah SMIPS dan pemboleh ubah Kriteria Rujukan pada Tingkah Laku Komunikasi dalam Penyelesaian Masalah (CAPS) pula, nilai $\mathrm{R}^{2}$ ialah 0.61 iaitu $61 \%$ yang juga menandakan hubungan sederhana kuat. Tahap motivasi seseorang individu sama ada tinggi atau rendah adalah dipengaruhi oleh sistem pertimbangan yang subjektif. Graduan lebih cenderung untuk melibatkan diri dalam tingkah laku komunikasi aktif berpandukan tahap motivasi yang dinyatakan berdasarkan pemboleh ubah antecedent situasi iaitu Pengenalpastian Masalah, Pengenalpastian Kekangan, dan Pengenalpastian Penglibatan. Dapatan kajian ini menunjukkan graduan perlu diberi pendedahan yang lebih komprehensif mengenai isu penguasaan kemahiran insaniah supaya mereka dapat meningkatkan kebolehan pengenalpastian masalah dan pengenalpastian penglibatan serta menyingkirkan batasan atau kekangan agar mereka sedar isu yang dihadapi boleh dibendung. Seterusnya, motivasi graduan untuk mencari jalan penyelesaian tercetus dan akhirnya mereka mula mengaktifkan tingkah laku komunikasi untuk menyelesaikan masalah penguasaan kemahiran insaniah.

\section{KESIMPULAN}

Kajian ini dijalankan untuk memahami isu penguasaan kemahiran insaniah yang dihadapi oleh graduan UKM menerusi perspektif Teori Situasi dalam Penyelesaian Masalah (STOPS). Hasil kajian mendapati model teori mencapai indeks kesepadanan yang baik dan menyokong hipotesis-hipotesis yang dicadangkan. STOPS menerangkan tindak balas publik (graduan) ke arah tingkah laku sosial iaitu dalam isu penguasaan kemahiran insaniah di mana dapatan kajian yang diperolehi mampu menyumbang kepada pembendungan masalah penguasaan kemahiran insaniah graduan. Pihak-pihak yang terlibat terutamanya institusi pengajian tinggi (IPT) wajar memberi penekanan terhadap isu penguasaan kemahiran insaniah graduan supaya masalah tersebut dapat diatasi seterusnya meningkatkan kadar kebolehpasaran graduan. Selari dengan hasrat itu, pihak universiti yang bertindak sebagai penyedia komponen kokurikulum perlu merangka semula inisiatif penguasaan kemahiran insaniah yang lebih berkesan agar mahasiswa bersedia menempuh cabaran baru di alam pekerjaan kelak. 
BIODATA

Ong Ai Ling merupakan calon Doktor Falsafah di Pusat Kajian Media dan Komunikasi (MENTION), Fakulti Sains Sosial dan Kemanusiaan, Universiti Kebangsaan Malaysia. Pengkhususan kajian beliau adalah dalam bidang perhubungan awam. Emel: josie.oal@gmail.com

Chang Peng Kee merupakan Profesor Madya di Pusat Kajian Media dan Komunikasi (MENTION), Fakulti Sains Sosial dan Kemanusiaan, Universiti Kebangsaan Malaysia. Beliau juga merupakan Pengarah di Pusat Pembangunan Karier-UKM. Bidang kepakaran beliau adalah perhubungan awam dan Media Framing. Emel: chang@ukm.edu.my

Arina Anis Azlan merupakan pensyarah kanan di Pusat Kajian Media dan Komunikasi (MENTION), Fakulti Sains Sosial dan Kemanusiaan, Universiti Kebangsaan Malaysia. Kepakaran beliau adalah dalam bidang pengurusan maklumat, komunikasi kesihatan dan tingkahlaku komunikasi dalam publik. Emel: arina@ukm.edu.my 


\section{RUJUKAN}

Ahmad Anuar, A., \& Esa, A. (2010). Penerapan kemahiran insaniah di Pusat Giat Mara (PGM): Satu analisis perbandingan. Dlm. Esa, A., \& Mustafa, M. Z. (pynt.), Kemahiran insaniah: Kajian di institusi-institusi pengajian (ms. 1-19.) . Batu Pahat: Penerbit UTHM.

Bentler, P. M. (1990). Comparative fit indexes in structural models. Psychological Bulletin, 107(2), 238-246.

Bentler, P. M., \& Bonett, D. G. (1980). Significance tests and goodness of fit in the analysis of covariance structures. Psychological Bulletin, 88, 588-606.

Byrne, B. M. (2010). Structural equation modeling with AMOS: Basic concepts, applications, and programming (2nd Ed.). New Jersey: Erlbaum.

Chin, W. W. (1998). Issues and opinion on structural equation modeling. MIS Quarterly, 22(1), 7-16.

Clarke, P., \& Kline, F. G. (1974). Media effects reconsidered: Some new strategies for communication research. Communication Research, 1(2), 224-240. https://doi.org/10.1177/009365027400100205

Cohen, J. (1988). Statistical power for the social sciences. Hillsdale, NJ: Laurence Erlbaum and Associates.

Demaria, M., Hodgson, Y., \& Czech, D. (2018). Perceptions of transferable skills among biomedical science students in the final-year of their degree: What are the implications for graduate employability?. International Journal of Innovation in Science and Mathematics Education, 26(7), 11-24.

Fairuzza Hairi, Mohamad Nazuir Ahmad Toee, \& Wahid Razzaly. (2011). Employers' perception on soft skills of graduates: A study of intel elite soft skill training. International Conference on Teaching \& Learning in Higher Education, 8(3), 1-8.

Flynn, K. M., Ho, P., Vieira, M. C., Pittia, P., \& Rosa, M. D. (2017). Food science and technology students self-evaluate soft and technical skills. International Journal of Food Studies, 6(2), 129-138. https://doi.org/10.7455/ijfs/6.2.2017.a1

Graham, E. E., Barbato, C. A., \& Perse, E. M. (1993). The interpersonal communication motives model. Communication Quarterly, 41(2), 172-186.

Grunig, J. E. (1997). A situational theory of publics: Conceptual history, recent challenges and new research. DIm. Moss, D., MacManus, T. \& Vercic, D. (Eds.), Public relations research: An international perspective (pp. 3-48). Haryana, India: International Thomson Business Press.

Hair, J. F., Black, W. C., Babin, B. J., \& Anderson, R. E. (2010). Multivariate data analysis (7th ed.). Englewood Cliffs: Prentice Hall.

Hamidah Norman, Rohailin Zainon, Siti Zuraydah Md Jenil, \& Rusyda Yahya. (2017). Personaliti graduan yang menjadi tarikan organisasi. Journal of Business Innovation Jurnal Inovasi Perniagaan, 2(1), 53-61.

Jalil, K. A. (2014). Publics' response towards smoking: A test of the situational theory of problem solving (Tesis Doktor falsafah, International Islamic University Malaysia).

Jin, B. (2007, November). Understanding collective efficacy as shared efforts from theory of reasoned action and situational theory of publics perspectives. Paper presented at National Communication Association Annual Meeting, Chicago, IL.

Kementerian Pendidikan Malaysia. (2018). Laporan kajian pengesanan graduan 2018. Retrieved from https://www.moe.gov.my/en/muat-turun/laporan-danstatistik/pendidikan-tinggi/laporan-kajian-pengesanan-graduan/2018-11/3157laporan-kajian-pengesanan-graduan-2018/file 
Kim, J. N., \& Vibber, K. (2012). Networked sociability and cybercoping: The effects of enabled personal networks and enhanced health outcomes among chronic health problem solvers. DIm. Duhe, S. (Ed.), New media and public relations (2nd ed). NY: Peter Lang.

Kim, J.-N., \& Grunig, J. E. (2011). Problem solving and communicative action: A situational theory of problem solving. Journal of Communication, 61(1), 120-149.

Kim, J.-N., \& Krishna, A. (2014). Publics and lay informatics: A review of the situational theory of problem solving. Annals of the International Communication Association, 38(1), 71105. https://doi.org/10.1080/23808985.2014.11679159

Kim, J.-N. (2006). Communicant activeness, cognitive entrepreneurship and a situational theory of problem solving (Doctoral dissertation. University of Maryland, College Park).

Kim, J.-N., \& Ni, L. (2013). Conceptualizing publics and constructing public relations theory: The situational theory of problem solving and its new research. In, Public relations and communication management: Current trends and emerging topics. NY: Routledge.

Kim, J.-N., Ni, L., Kim, S. H., \& Kim, J. R. (2012). What makes people hot? Applying the situational theory of problem solving to hot-issue publics. Journal of Public Relations Research, 24(2), 144-164.

Kim, J.-N., Shen, H., \& Morgan, S. E. (2011). Information behaviors and problem chain recognition effect: Applying situational theory of problem solving in organ donation issues. Health Communication, 26(2), 171-184.

Krishna, A. (2017). Motivation with misinformation: Conceptualizing lacuna individuals and publics as knowledge-deficient, issue-negative activists. Journal of Public Relations Research, 29(4), 176-193.

Marsh, H. W., \& Hocevar, D. (1985). Application of confirmatory factor analysis to the study of self-concept. First- and higher order factor models and their invariance across groups. Psychological Bulletin, 97, 562-582.

Norliana Hashim. (2017). Komitmen organisasi dan dinamika publik terhadap kebolehpasaran graduan: Satu usaha kembangan teori situasi dalam penyelesaian masalah (Tesis Doktor falsafah, Universiti Kebangsaan Malaysia).

Norliana Hashim, Chang Peng Kee, \& Mat Pauzi Abd. Rahman. (2016). Stops: Addressing graduate marketability issue in Malaysia. Jurnal Komunikasi: Malaysian Journal of Communication, 32(2), 139-164.

Noor Lela Ahmad, \& Suraini Mohd Rhouse. (2016). Kemahiran profesional graduan perakaunan: Antara jangkaan majikan dan keperluan pelajar dalam kurikulum perakaunan. Jurnal Pendidikan Malaysia, 41(1), 7-17.

Noor Lela Ahmad, Noraishah Buang, \& Norasmah Othman. (2012). Amalan penerapan nilai murni dalam kalangan pendidik perakaunan. Management Research Journal, 1, 5474.

Norasmah Othman. (2017). Daya tahan pelajar universiti awam dan universiti swasta. Jurnal Pendidikan Malaysia, 42(1), 77-86.

Sarkar, M., Overton, T., Thompson, C., \& Rayner, G. (2016). Graduate employability: Views of recent science graduates and employers. International Journal of Innovation in Science and Mathematics Education, 24(3), 31-48.

Wats, M., \& Wats, R. K. (2009). Developing soft skills in students. International Journal of Learning, 15(12), 1-10.

Zainudin Awang, Lim Siew Hui, \& Nur Fairuza Syahira Zainudin (2018). Pendekatan mudah SEM. Bangi: MPWS Rich Publication. 